مقاله يخوهشى

مجله دانشعاه علوم يزشكى رفسنجان

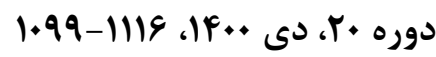

مقايسه مقبوليت اجتماعى، اختلالات سلوكى و دشوارى در تنظيم هيجان در كود كان كان طلاق،

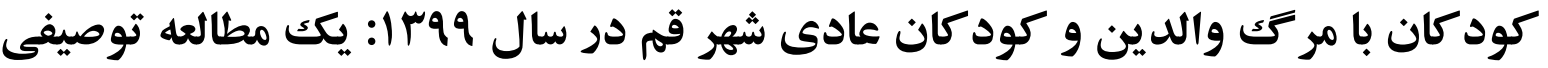

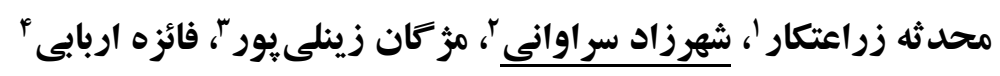

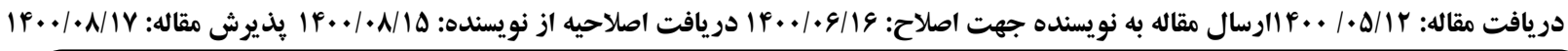
زمينه و هدف: تجربه جدايى و مرك والدين مىتواند به مشكلات روانشناختى و رفتارى زيادى منجر شود. هدف يزوهش

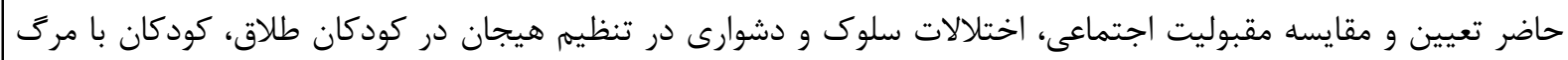
والدين و كودكان عادى بود. مواد و روشها: در اين مطالعه توصيفى، تعداد • 11 دانشآموز مقطع متوسطه اول و ششم ابتدايى مشغول به تحصيل در شهر

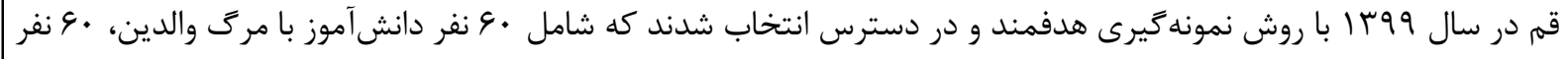

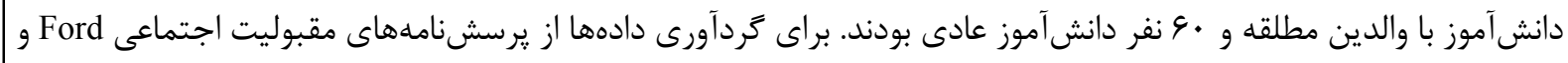

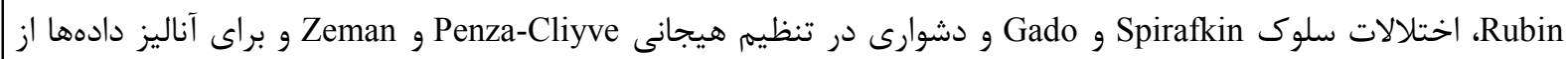
تحليل واريانس קندمتغيره استفاده شد.

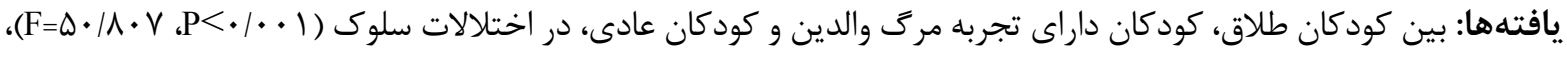

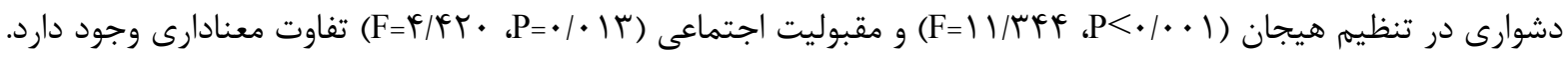

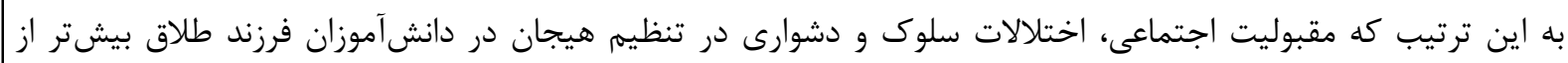

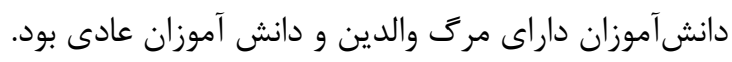
نتيجهَيرى: بر اساس نتايج يزوهش، ميزان اختلالات سلوك و دشوارى در تنظيم هيجانى در كودكان طلاق بيشتر از كودكان

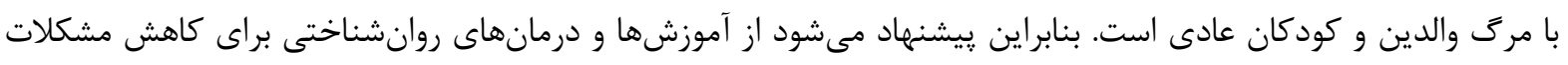

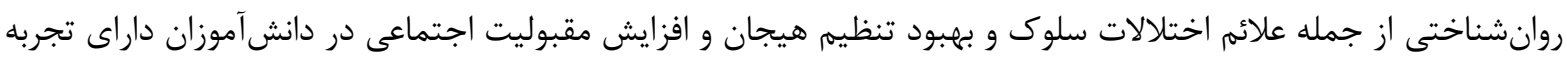
طلاق والدين و مرك والدين استفاده شود. وازههاى كليدى: مقبوليت اجتماعى، اختلالات سلوك، مرى والدين، طلاق، كودكان، قم

$$
\begin{aligned}
& \text { 1- كارشناس ارشد، گروه مشاوره خانواده، واحد قم، دانشكاه آزاد اسلامى، قم، ايران }
\end{aligned}
$$

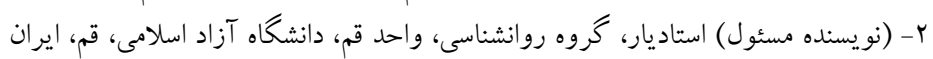

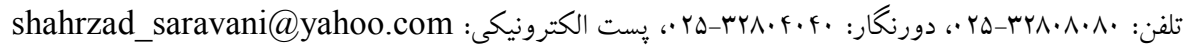

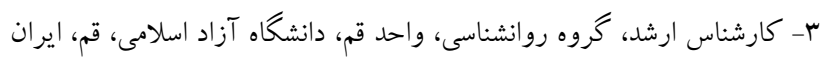

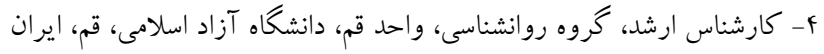


روانيزشكى بهويزه اختلالات مصرف الكل و مواد مخدر منجر

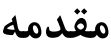

مىشود و سلامت عمومى در افرادى كه مرك يدر و مادر را تجربه كردهاند پايينتر از فرزندان عادى و طلاق مىباشد [N]. همجنين يافتههاى يزوهش Amato و Anthony با هدف تعيين اثرات طلاق و مرگ والدين نشان داد كه طلاق و مرى والدين ييامدهاى منفى زيادى براى كودكان دارند و طلاق والدين منجر به بيامدهاى منفى بيشترى مىشود [9]. Urie ) بهلاوه، مطابق با نظريه سيستمهاى بوم شناختى (Bronfen Brenner Ecological Systems Theory كه Bronfen Brenner در سال 199 ارائه داد رفتار كودكان رامىتوان بر آيندى از تأثير ييوندهاى اجتماعى مانند مقبوليت اجتماعى، ويزگى هاى فردى مانند سرشت هيجانيذير و حتى تأثير روابط والدين با كودكان و نحوه سازگارى بين آنها دانست كه گاه اختلالات روانشناختى مانند اختلالات سلوى

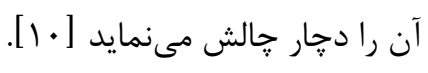

مقبوليت اجتماعى (Social acceptability) همان كرايش به پاسخ دادن به شيوهاى است كه فرد در نظر ديكران بهتر جلوه كند. مقبوليت اجتماعى موجب بروز رفتارهاى مناسب و عملكرد اجتماعى مثبت در كودكان شده و باعث مىشود كه آنها از طرف همسالان مورد تحسين و احترام قرار بخيرند [11][ هر انسانى نياز مبرم به مقبوليت اجتماعى از طرف خانواده، دوستان، مدرسه و جامعه دارد جون مقبوليت اجتماعى فرد را در برابر انواع مشكلات جسمى و روحى مقاوم مى كند و به او اعتماد به نفس كافى در مقابل مشكلات زندگى مى دهد [ I I]. از نظر والدين و معلمان، كودكانى كه فاقد

محيط خانواده مهمترين عامل در يادكيرى و رشد كودكان و جايگاهى امن براى ارضاء نيازهاى گَناكون جسمانى، عقلانى و عاطفى آنان است كه آَكاهى و شناخت جَكَنكى ارضاء آنها بسيار ضرورى است [1]]. معمولاً عوامل گوناگون فردى، اجتماعى، عاطفى و روانشناختى پايدارى و انسجام اين نهاد ديرينه و سازنده اجتماعى را تضعيف مى كنند [r]]. از جمله مشكلات خانوادىى كه مىتواند به مشكلات روانشناختى كودكان منجر شود طلاق و مرى والدين است كه به عنوان دو عامل فشارزاى دوران رشد در نظر گرفته مىشوند [ب]. طلاق موجب تغيير در ساختار خانواده و ايجاد فشار و استرس براى تمامى اعضاى خانواده است و اغلب موجب كاهش سازكارى روانشناختى مىشود [ع]. تحقيقات نشان دادهاند كه رابطه بين طلاق و سلامت روانشناختى فرزندان بسيار پِيجيده است. داشتن شغلهاى سطح پإين، تحصيلات دانشخاهى پايين، روابط بىثبات با والد همراه، ترس از تعهد و طلاق در زندگى زناشويى، مصرف بيشتر الكل در نوجوانى، بزهكارى و كاهش خودينداره مثبت از جمله مشكلات احتمالى اين كودكان محسوب مىشود [ه]]. حادثه استرسزاى مرى والدين موجب مشكلات روانشناختى مانند افسردگى [ع]، ميزان گِيين اشتغال و مشكلات شغلى، عزت نفس پايين، ناتوانى در برقرارى روابط

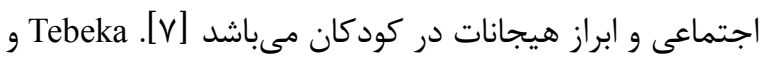
همكاران در يك مطالعه با هدف ارتباط طلاق يا مرى والدين در دوران كودكى و نوجوانى با سلامت روان نشان دادند كه سابقه طلاق والدين به شيوع قابل توجهى از اختلالات 
است [19]. Scharfstein و Beidel نشان دادند كه كودكان داراى اختلالات سلوك پِاسخهاى اجتماعى غيرمؤثرى دارند و اين امر موجب مىشود كه آنها مورد يذيرش همسالان قرار نخيرند [r] [ب] بنا بر آنجه ذكر شد طلاق و مرگ والدين از رويدادهاى استرسزايى هستند كه بر كودكان تأثيرات روانى-اجتماعى زيادى دارند. از اين رو، توجه به ييامدهاى روانى-اجتماعىهيجانى طلاق و مرك والدين و مطالعه متغيرهاى ايجادكننده آن مانند مقبوليت اجتماعى، اختلالات سلوك و دشوارى تنظيم هيجان مىتواند به روانشناسان و درمان كند تا بتوانند با استفاده از درمانها و آموزشهاى روانشناختى به حل مشكلات اين كودكان بيردازند. همرجنين با توجه به اين كه بزوهش هاى حذشته به مقايسه تأثيرات مرى والدين و طلاق بر علائم مقبوليت اجتماعى، اختلالات سلوى و دشوارى در تنظيم هيجان نيرداخته و بلطور ويزه اين سه متغير رادر كودكان طلاق و كودكان داراى تجربه مرك والدين مورد بررسى قرار نداده است؛ بنابراين مطالعه حاضر با هدف تعيين و مقايسه مقبوليت اجتماعى، اختلالات سلوك و دشوارى در تنظيم هيجان در كودكان طلاق، كودكان با مرى والدين و كودكان عادى شهر قم در سال 99 با اجرا گرديد.

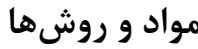

يزوهش حاضر از نوع توصيفى بود. جامعه مورد يزوهش شامل دانشآموزان كلاس ششم مقطع ابتدايى و كلاس هفتم، هشتم و نهم مقطع متوسطه اول شهر قم در سال 99 1 بودند كه داراى تجربه طلاق و يا مرگ والدين بودند و يا هيجكدام از اين عوامل فشار زا را تجربه نكرده بودند. براى محاسبه حجم
مقبوليت اجتماعى هستند انواع مشكلات هيجانى و

اجتماعى را تجربه مى كنند و رشد نامطلوبى دارند [1 ا ]. محقق از مشاهدات تجربى خود جنين استنباط كرد كه عواملى همجون اختلال سلوك و دشوارى تنظيم هيجان مىتواند بر مقبوليت اجتماعى تأثيركذار باشند. اختلالات سلوى (Mental disorders) كه يكى از اختلالهاى رفتارى دوران كودكى و نوجوانى را تشكيل مىدهد الخوى رفتارى پايدار و تكرار شوندهاى مشتمل بر نقض حقوق اساسى ديگران و تجاوز از هنجارهاى اصلى اجتماعى متناسب با سن كودى يا نوجوان تعريف شده است. ناتوانى در حل مسئله، عزت نفس پايين، رفتارهاى يرخاشكرانه و ناسازگارانه، ضعف در عملكرد تحصيلى و ناتوانى در مهارتهاى اجتماعى كلامى و غير كلامى از ييامدهاى اختلالات سلوك است [ع ا []. اختلالات سلوك در دوره كودكى و نوجوانى اثرات نامطلوبى بر زندگى آينده وى مى گذارد؛ بزرگسالانى كه در كودكى مبتلا به اختلالات سلوك تشخيص داده شده بودند از سلامت جسمانى و روانى كمترى برخوردار و در زمينه فرزنديرورى نيز با مشكلات بيشترى روبرو بودند [ها]] تنظيم هيجان (Emotional regulation) نيز يكى از متغيرهاى مرتبط با اختلالات رفتارى و سلوك است [ع] به اين معنى است كه جِكونه يك فرد يك تجربه هيجانى را از طريق رفتارهاى كلامى و غير كلامى بيان مىكند [IV]]. تنظيم شناختى هيجان شامل نظارت، ارزيابى و اصلاح واكنشهاى هيجانى به ويزه حالتهاى شديد و زودگذر هيجانى به منظور رسيدن به اهداف است [11]]. هيجانات منفى با طرد و هيجانات مثبت با مقبوليت اجتماعى مرتبط 
به عنوان گروه كنترل نيز استفاده شد. هر سه گروه از نظر سن، پايه تحصيلى و جنسيت همتاسازى شدند. در هر مدرسه محقق با توجه به آمار موجود هر سه گروه، توضيحات لازم را به آزمودنىهاى شركت كننده در يزوهش ارائه داد و رضايتنامه كتبى از آنها كسب كرد و سيس به توزيع برسشنامهها به صورت فردى يرداخت. در اين تحقيق براى پاسخ به دو يرسشنامه خودَزارشى مقبوليت اجتماعى و تنظيم هيجانى كه توسط دانش آموزان تكميل شد • 1 دقيقه فرصت داده شد اما يرسشنامه اختلالات سلوك (فرم والد) توسط يكى از والدين دانشآموز كه آنجا حضور داشت تكميل شد. تمامى :رسشنامهها در زمان اخذ از واحدهاى يروهش بررسى شد تا جنان جه شركت كننده به سؤالى پاسخ نداده بود مجدداً از وى درخواست شود كه يرسشنامهها را به صورت كاملاً تكميل شده تحويل دهد. جهت در نظر داشتن ملاحظات اخلاقى در اين يزوهش اطلاعات ارائه شده در قالب يرسشنامهها تنها در اختيار محقق بوده و از دستيابى افراد ديخر به اين كونه اطلاعات ممانعت به عمل آمد تا اصل رازدارى رعايت گردد. همجزنين افراد شركت كننده مختار بودند كه در هر زمانى كه بخواهند يزوهش را ترك نمايند. ويزگى هاى جمعيت شناختى در اين يزوهش شامل سن، پايه تحصيلى و جنسيت بود.

يرسشنامه مقبوليت اجتماعى: اين مقياس توسط Ford و Rubin كودكان ساخته شد و داراى عץ گويه بسته پِاسخ است. آنها يرسشنامه را بر روى VFr نفر از كودكان دبستانى اجرا و همسانى درونى را براى كودكان دبستانى دختر و يسر به
نمونه با توجه به اينكه حداقل حجم لازم در تحقيقات توصيفى براى هر كروه نبايد كمتر از •ـr نفر باشد [آr]، لذا

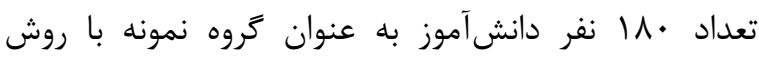
9. 9مونه گيرى هدفمند و در دسترس انتخاب شدند كه شامل

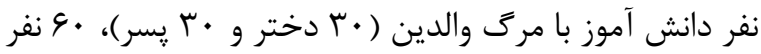
دانش آموز با والدين مطلقه (•r دختر و •r يسر) و •ع نفر دانش آموز عادى داراى هر دو والد (·r دختر و •r يسر)

ملاك ورود به نمونه شامل نداشتن اختلال حاد روحى و روانشناختى با توجه به يرونده سلامت دانشآموز، كسب رضايت والدين و توانايى پاسخ به يرسشنامه بود. ملاك خروج از نمونه شامل داشتن اختلال رفتارى و روانى شديد با توجه به يرونده سلامت دانشآموز، عدم تمايل به شركت در يزوهش و تكميل ناقص يرسشنامهها بود. براى انجام يزوهش، محقق پِ از كسب مجوزهاى لازم و دريافت شناسه اخلاق شخصاً جهت يخش :رسشنامهها از دى ماه تا اسفند ماه 99 ا در شهر قم در طى ساعت حضور دانش آموزان در شيفت صبح اقدام كرد. محقق با مراجعه به مدارس مقطع ابتدايى و متوسطه اول شهر قم و ارائه مدارك مربوط به انجام تحقيق از مديران مدرسه درخواست نمود بر اساس يرونده تحصيلى، اسامى دانشآموزانى كه يكى از والدين يا هر دوى آنها فوت نمودند، دانشآموزانى كه والدين آنها به علت طلاق از هم جدا شده بودند، در اختيارشان قرار دهد. بعد از شناسايى دانشآموزان با مرى والدين و دانش آموزان با تجربه طلاق والدين، به همان تعداد به صورت در دسترس از كودكان عادى 
منظور غربال 11 اختلال رفتارى و هيجانى در كودكان و نوجوانان طراحى شد. اين :رسشنامه داراى دو جـى ليست والد و معلم است كه در اين تحقيق از جـى ليست والد استفاده شده است. جك ليست والد VV سؤال براى سنجش VI اختلال دارد كه ها سؤال آن مربوط به ارزيابى اختلالات سلوك است. هر عبارت در جك ليست در يك مقياس أ درجهاى (هرگز=) ا،

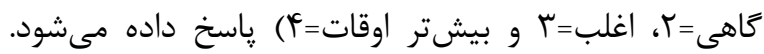
بنابراين حداقل نمره كلى ها و حداكثر آن •و مي باشد. سؤالات مربوط به ارزيابى اختلالات سلوك ه خرده مقياس يرخاش گرى (سؤال ا الى ؟)، بىمسئوليتى (سؤال ؟ الى ع)، فريبكارى (سؤال V الى 9)، خراب كارى (سؤال • ا الى Y ) و روابط ضعيف بين فردى (r ا الى ه| ) را مىسنجد كه حداقل

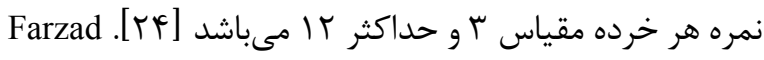
و همكاران در يزوهشى مقدار ضريب يايايى آن را به روش هماهنگى درونى براى فرم والد 94/ • و براى فرم معلم 99/. گزارش كردند [هץ]. در مطالعه حاضر :ايايى با استفاده از ضريب آلفاى كرونباخ عدد • ^| • به دست آمد كه نشان دهنده يايا بودن يرسشنامه است.

يرسشنامه تنظيم شناختى هيجان: اين يرسشنامه توسط Penza-Cliyve و Zeman در سال r +. كه داراى عا گويه است. شيوه ياسخدهى به گويههاى آن بر اساس مقياس ينجدرجهاى ليكرت (اصلاً درست نيست = ا،

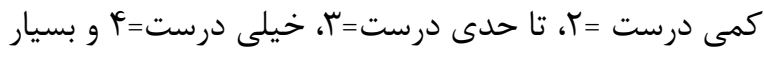
درست=لف) است. اين :رسشنامه دو عامل آكاهى ضعيف تنظيم هيجانى (سؤالات ا الى 1 ) ) ضعف در ابراز هيجان

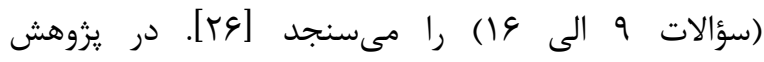

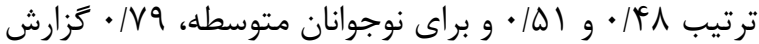
كردند. سيس يايايى به روش بازآزمايى را يس از ينج هفته ه ه • • به دست آوردند و اعتبار همزمان يرسشنامه را بر اساس بهره هوش كلامى محاسبه كردند كه حاكى از همبستخى معنادار دو متغير بود. به طور كلى كودكانى كه نمره بالاترى در مقبوليت اجتماعى دريافت كردهاند، ياسخ مثبت بيشترى به تقاضاهاى بين فردى مى دهند [Tr]]. Samouee و همكاران در سال سمسا اين مورد را مورد بررسى قرار دادند. همسانى درونى سؤالات در اين مرحله حكايت از آن داشت كه هشت

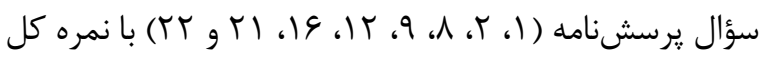
همبستخى ندارد. بنابراين از فرم اصلى حذف شدند و در مرحله

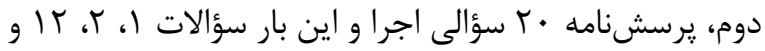
rا نامناسب تشخيص داده شد و به جز سؤال r| حذف شدند؛ البته سؤال ץا مورد ويراستارى قرار گرفت. در مرحله سوم، فرم IV سؤالى اجرا شد و نتايج همسانى درونى در اين مرحله حكايت از آن داشت كه نمرات هر IV سؤال سهزينهاى "بله"، اتا حدودى" و "خير" تنظيم و نمرهگذارى )، † و صفر را شامل شد. حداقل نمره هر فرد در يرسشنامه صفر و حداكثر ب است. نمرهى بيشتر نشان دهنده مقبوليت اجتماعى بالاتر و برعكس است. ضريب الفاى اين :يرسشنامه • • و ضريب ضريب پايايى به روش دو نيمه سازى 9 دست آمد [سץ]. در : يزوهش حاضر ضريب آلفاى كرونباخ اين مقياس NT/ • محاسبه شد. يرسشنامه علايم مرضى كودكان: جهت سنجش اختلالات سلوك از يرسشنامه علائم مرضى كودكان استفاده شد. اين مقياس اولين بار توسط Spirafkin و Gado در سال 919 به 
ميزان آلفاى كرونباخ اين مقياس براى عامل مورد بررسى از تحليل واريانس جندمتغيره و آزمون تعقيبى

حداقل اختلاف معنى دار ) Least significant difference; (LSD استفاده شد. سطح معنى دارى در آزمونها هـ/• در نظر ترفته شد.

ميانگين و انحراف معيار سنى كروه كودكان طلاق •

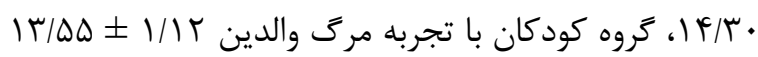

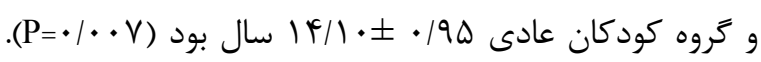
نتايج آزمون مجذور كاى نشان داد كه بين گروهها از نظر اطلاعات جمعيت شناختى شامل گروههاى سنى، پِايه تحصيلى و جنسيت تفاوت آمارى معنادارى وجود داشت

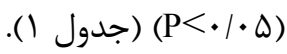

آكاهى ضعيف تنظيم هيجانى و ضعف در ابراز هيجان به ترتيب

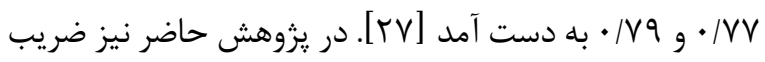
آلفاى كرونباخ دو مقياس بالا به ترتيب ل/V| • و • • به دست

دادهها يس از جمعآورى با استفاده از نرمافزار SPSS نسخه Fץ مورد تجزيه و تحليل قرار گَرفتند. نتايج براى دادههاى كمى به صورت ميانگين و انحراف معيار و براى دادههاى كيفى به صورت تعداد (درصد) گَزارش گرديد. به منظور مقايسه ويزَّىهاى كمى و كيفى در سه گروه مورد بر رسى از آزمون مجذور كاى و آناليز واريانس يكطرفه استفاده شد. همرجنين به منظور مقايسه همزمان ميانگين نمرات مقبوليت اجتماعى، دشوارى در تنظيم هيجانى و اختلالات سلوك در گروههاى

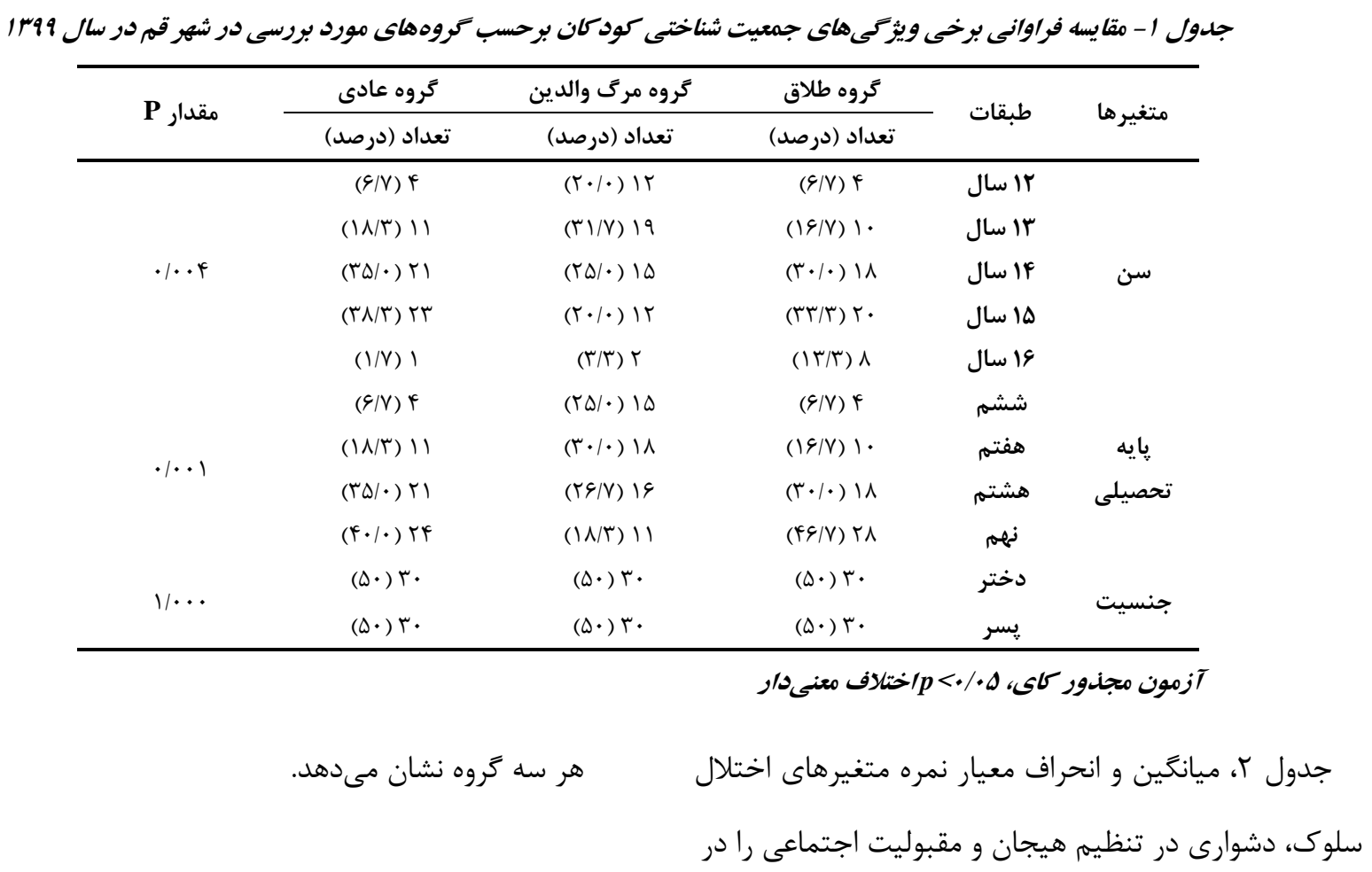


جدول r- ميانكين، انحراف استاندارد، حداقل و حداكثر نمرات متغيرهاى بزوهش در كودكان طلاق، كودكان داراى تجربه مركك والدين و كودكان

عادى در شهرقم در سال 149

\begin{tabular}{|c|c|c|c|c|c|c|c|c|c|c|c|c|}
\hline \multirow[b]{2}{*}{ حداكثر } & \multicolumn{2}{|c|}{ كروه عادى } & \multirow[b]{2}{*}{ ميانگين } & \multirow[b]{2}{*}{ حداكثر } & \multicolumn{2}{|c|}{ مرى والدين } & \multirow[b]{2}{*}{ ميانغين } & \multicolumn{4}{|c|}{ تروه طلاق } & \multirow[b]{2}{*}{ متغيرها } \\
\hline & حداقل & استاندارد & & & حداقل & استاندارد انحراف & & حداكثر & حداقل & استاندارد & ميانغين & \\
\hline id & $r \cdot$ & $1 \cdot 1 \Delta T$ & TT/VV & is & rr & $1 \cdot / \mathrm{N} \Lambda$ & TG|A| & $i \Delta$ & rT & IT/GT & $r \cdot / \Lambda$. & سلوى اختلال \\
\hline$\Delta \Delta$ & rq & $\mid \pi / \cdot$ & एव/vq & $\Delta \Delta$ & ץ & $9 / \%$. & $F \Delta / A \Lambda$ & $\Delta \Delta$ & r. & $1 \pi / 9$. & $\uparrow q / 90$ & دينظيم \\
\hline 19 & $1 \cdot$ & S/AD & $1 N / T V$ & 11 & 9 & $\Delta / \bar{c}$. & $19 / V 9$ & 19 & 11 & $9 / T$. & $\mid f / \Lambda$. & اجتماعى اجيت \\
\hline
\end{tabular}

سطح معنادارى به دست آمده از آزمون تحليل واريانس جندمتغيره نشان داد كه تفاوت بين سطح متغير مستقل در تركيب خطى متغيرهاى وابسته معنادار است و بين گروهها در حداقل يكى از متغيرهاى وابسته تفاوت معنادارى وجود دارد

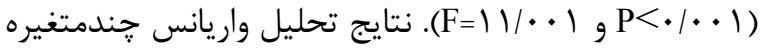
نيز نشان داد بين كودكان طلاق، داراى تجربه مرگ والدين و كودكان عادى در ميانگين نمرات اختلالات سلوك

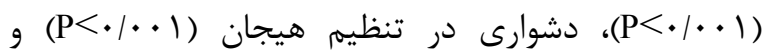

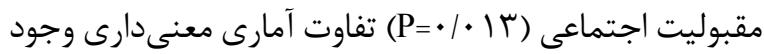
دارد. اندازه اثر (كه در واقع مجذور ضريب همبستكى بين متغيرهاى وابسته و عضويت گروهى است) نشان داد كه تفاوت بين سه گروه با توجه به متغيرهاى وابسته در مجموع معنىدار است و ميزان اين تفاوت تقريباً \م درصد است. يعنى درصد از تغييرات متغيرهاى وابسته ناشى از متغير مستقل

$$
\text { بوده است (جدول r). }
$$

״يش از تحليل دادهها با آناليز واريانس جندمتغيره ييشفرض هاى آن بررسى شد و نتايج نشان داد كه بر اساس آزمون Kolmogorov-Smirnov فرض نرمال بودن براى متغيرهاى اختلال سلوك، دشوارى تنظيم هيجان و مقبوليت اجتماعى برقرار است (19=|(P=). قبل از اجراى تحليل واريانس جندمتغيره براى مقايسه اختلال سلوك، دشوارى در تنظيه هيجان و مقبوليت اجتماعى، ابتدا آزمون ام باكس جهت بررسى شرط همخنى ماتريسهاى (Box's M) كواريانس به عمل آمد كه نتايج نشان داد شرط همگنى

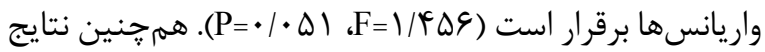
نشان داد شرط همخنى واريانسها با استفاده از آزمون Levene براى علايم اختلالات سلوك (P=• I V (P)، دشوارى در تنظيم هيجان ( (P=//) و مقبوليت اجتماعى

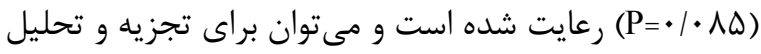
استنباطى دادهها از آزمون گارامتريك استفاده نمود. 
9. 11 مقايسه مقبوليت اجتماعى، اختلالات سلوكى و دشوارى در تنظيم هيجان در كود كان طلاق ...

جدول بـ - خلاصه نتا يج تحليل واريانس جنلدمتغيره بر روى ميانتين نمرات متغيرهاى مورد بررسى

\begin{tabular}{|c|c|c|c|c|c|c|c|}
\hline اندازه اثر & مقدار P P & درجه آزادى خطا & درجه آزادى فرضيه & Fقدار F F F & ارزش & آزمون & اثر \\
\hline$\cdot / T \wedge \Delta$ & $<\cdot / \cdot \cdot 1$ & MFF & 4 & IY/DG & $\cdot / r \wedge r$ & اثر بيلايى & \multirow{4}{*}{ كروه } \\
\hline$\cdot / r \wedge \Delta$ & $<\cdot / \cdot \cdot 1$ & MFt & 9 & $10 / \& q$. & .1919 & لامبداى ويلكز & \\
\hline$\cdot / T \wedge \Delta$ & $<\cdot / \cdot \cdot 1$ & rF. & 4 & $\mid V / r \& 9$ &.$|9| r$ & اثر هولتينغ & \\
\hline$\cdot / r \wedge \Delta$ & $<\cdot / \cdot \cdot 1$ & IVT & r & $r F / 9 . q$ & $.19 \cdot 9$ & بزركترين ريشه روى & \\
\hline
\end{tabular}

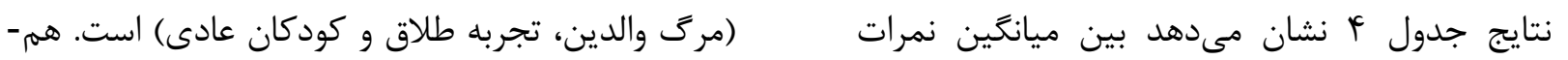
اختلال سلوك، دشوارى در تنظيم هيجانى و مقبوليت جنين 1/9 درصد تفاوت در نمرات دشوارى در تنظيم

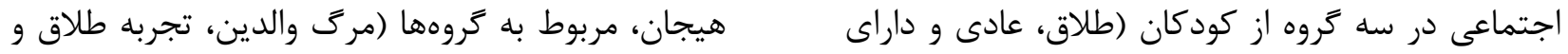

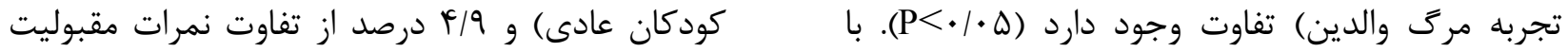
توجه به اينكه ميانگين سنى و توزيع فراوانى يايه اجتماعى، مربوط به گروههاى مرگ والدين، تجربه طلاق تحصيلى در كروههاى مورد بررسى تفاوت آمارى كودكان عادى است كه نتايج تحليل واريانس معنى دارى با يكديخر داشتند، بنابراين اثرات سن و پايه جندمتغيره نشان داد بين سه گروه از كودكان (طلاق، تحصيلى در تحليل واريانس جندمتغيره كنترل گرديد. داراى تجربه مرگ والدين و عادى) در ميانگین نمره

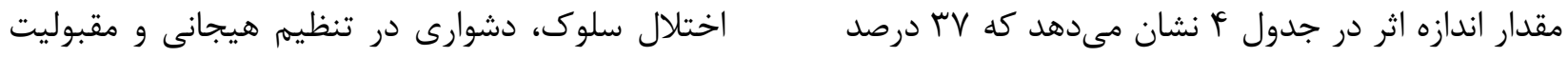
تفاوت در نمرات اختلالات سلوك، مربوط به گروهها اجتماعى تفاوت معنىدار وجود داشت ( • • • (P>). جدول ب - نتايج آناليز واريانس جندمتغيره مقايسه اختلالات سلوك، دشوارى در تنظيم هيجانى و مقبوليت اجتماعى در كودكان مورد مطالعه در شهر قم

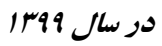

\begin{tabular}{|c|c|c|c|c|c|c|c|}
\hline اندازه اثر & مقدار P" & مقدار F & مجذانگين & درجه & مجذورع مجموع & متغير & كروه \\
\hline$\cdot / \pi v$. & $<\cdot \mid \cdot \cdot 1$ & $\Delta \cdot / \Lambda \cdot V$ & Drrq/Irq & $r$ & $1 \cdot V I N / T \Delta \Lambda$ & اختلالات سلوى & \\
\hline .1119 & $<\cdot / \cdot \cdot 1$ & $11 /$ MEF & $\mid \Delta \Delta \wedge / \Delta \wedge r$ & r & TIV/gIV & دشوارى در تنظيم & كروه \\
\hline $.1 \cdot 49$ & r & F/FT. & IVr/Arq & r & TFV/GVq & مقبوليت اجتماعى & \\
\hline
\end{tabular}

*ق كنترل شده براى اثرات سن و بإيه تحصيلى 
ميانگين دشوارى در تنظيم هيجان گروه كودكان طلاق

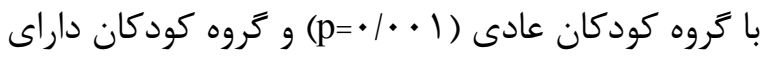

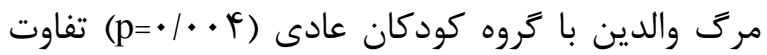
معنادارى وجود داشت. بين ميانخين ميزان مقبوليت اجتماعى گروه كودكان طلاق با كودكان عادى نيز تفاوت

$$
\text { معنادار بود (r + • (p=). }
$$

براى مقايسه زوجى گروهها با يكديگر از آزمون تعقيبى LSD استفاده شد (جدول ه). نتايج بيانگر آن بود كه بين ميانگينهاى اختلالات سلوك در گروه

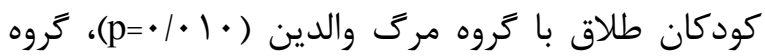
كودكان طلاق با گروه كودكان عادى ( ( • (p=) و گروه كودكان داراى مرگ والدين با گروه كودكان عادى تفاوت معنادارى وجود داشت. همرجنين بين

جدول ه- مقا يسه زوجى بين سه كروه كودكان (طلاق، داراى تجربه مركى والدين و عادى) بر اساس نمره اختلال

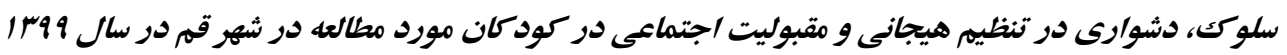

\begin{tabular}{|c|c|c|c|c|c|}
\hline Pقدار P P & خطاى استاندارد & تفاوت ميانكينها & & تروه & متغير \\
\hline.$/ \cdot 1$ & $1 / 991$ & Q/ITI & مرك والدين & طلاق & اختلالات سلوك \\
\hline$\cdot 1 \cdot \cdot 1$ & $1 / \wedge \Lambda 1$ & IN/Tr. & عادى & & \\
\hline$\cdot 1 \cdot \cdot 1$ & $1 / 9 r \wedge$ & $1 \% / 1 \wedge 9$ & عادى & مرك والدين & \\
\hline .1 .99 & T/TYS & $r / v \Delta \Delta$ & مرى والدين & طلاق & دشوارى در تنظيم هيجان \\
\hline$\cdot 1 \cdot \cdot 1$ & T/lFV & $-1 \cdot 1 \cdot 19$ & عادى & & \\
\hline $.1 \cdot r$ & $r / T .$. & سחس/g- & عادى & مرى والدين & \\
\hline$.|| f \mid$ & $1 / T \cdot r$ & $-1 / V V V$ & مرى والدين & طلاق & مقبوليت اجتماعى \\
\hline • & $1 / 149$ & $-r / Y \mid Q$ & عادى & & \\
\hline .1199 & I/VVV & $-1 / 94 \wedge$ & عادى & مرى والدين & \\
\hline
\end{tabular}

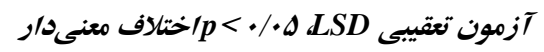

كودكان طلاق، كودكان با مرى والدين و كودكان عادى 
كودى حمايت هيجانى و عاطفى دارد، موجب مىشود كه وى محيط اطراف را تهديدآميز در نظر بخيرند و به احتمال زياد علائم اختلالات سلوى از جمله اختلال وحشت زدگى، اضطراب فراگير، اضطراب جدايى، اضطراب اجتماعى در آنان بيشتر خواهد شد كه خود اين امر مىتواند به يك مشكل رفتارى جدى مانند اجتناب از مدرسه (كه يكى از ابعاد اختلالات سلوك در يرسشنامه مورد استفاده بود)، منجر شود. در مورد ميزان بيشتر اختلالات سلوى در گروه كودكان مواجه با طلاق والدين نسبت به كودكان مواجه با مرى والدين و كودكان عادى جنين احتمال مىدهند كه طلاق والدين مجموعه وسيعى از تغييرات و سازماندهى هاى مجدد را در خانواده ايجاد مى كند كه در طول زمان بر سازگارى كودى تأثير مى گذارد و موجب مىشود كه كودكان به دليل داشتن سن كم مهارتهاى ناكارآمد در برخورد با شرايط جديد و داشتن ملاقاتهاى مكرر با والد جدا شده، ساختار جديد خانواده را نيذيرند و بيشترين آسيب را متحمل شوند ولى كودكان داراى تجربه مرگ والدين معمولا مرگ والدين و نبود آنها را بعد از فرايند سوگ مىيذيرند و حالتهاى اضطراب و نشانههاى آن را كمتر بروز مىدهند. از طرفى همسو با نتايج Kahani و Hassanabadi [اب] مىتوان اذعان
كودكان عادى بوده است. اين نتيجه همخوان با يافتههاى قبلى است كه نشان دادند اختلالات سلوى يك مشكل اساسى در كودكان طلاق است [^^]. همرجنين با يافتههاى قبلى همخوان است كه ميزان بالايى از اضطراب

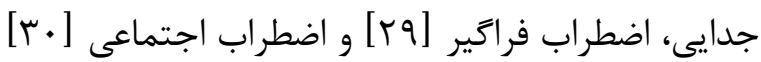
را در كودكان طلاق گزارش كردهاند. بهعلاوه، اين نتيجه همسو با يافتههاى قبلى نيز هست كه ميزان شيوع علائم اختلالات وحشتزدكى، كَرهراسى، اختلال اضطراب اجتماعى، اضطراب فراگير، هراس خاص و اضطراب جدايى را در كودكان داراى تجربه مرگ يكى از والدين بيشتر از كودكان عادى گزارش كردند [^^]. در مورد طلاق و مرى والدين و تأثير آن بر اختلالات سلوى كودكان كَته مىشود كه با توجه به اهميت رابطه كودى با والد و دلبستخى ميان آنها در صورت عدم ارضاء نيازهاى عاطفى كودكان به دليل طلاق يا مرى والدين، اين كودكان تجربه فقدان و ناكامى ناشى از اين دو حادثه استرسزا را از طريق فشارهاى روحى و هيجان هاى منفى به ويزه اضطراب يا اختلالات سلوك نشان خواهند داد زيرا در يزوهشهاى كذشته تجارب منفى دوران كودكى مانند فقدان والد مراقبت كننده يكى از عوامل ايجاد اختلالات سلوك در نظر گرفته شده است [اب]]. بنابراين مىتوان كفت كه فقدان والدين يا والدى كه نسبت به 
زمان انجام اين يزوهش مطالعهاى انجام نشده است، اما برخى يزوهشها به مشكلات هيجانى كودكان طلاق [•r] و كودكان مواجه با مركى والدين [بر] اشاره كردهاند و برخى يزوهشها اثر مرى والدين را بر مشكل در توانايى كنترل هيجانها [وَ] و بهزيستى هيجانى يايين [^/r] كودكان تأييد كرداند. در تبيين اين يافته طبق يزوهشهاى قبلى كفته مىشود كه عدم حضور والدين به دليل طلاق و جدايى يا مرك اثرات روانشناختى كوتاه مدت و بلندمدتى بر كودكان مى كذارد [ه]. به عنوان نمونه، كودكان داراى تجربه مرك والدين به دليل فقدان والد از دست رفته، تنهايى و كَشهَيرى [rی] را انتخاب مى كنند كه خود اين امر مىتواند به كاهش ابراز هيجان در آنان به ويزه در موقعيتهاى اجتماعى منجر شود. به عبارت ديكر، كودكان طلاق و داراى تجربه مرك والدين ممكن است فقدان والد خود را از طريق ابرازهاى هيجانى بايين در روابط اجتماعى نشان دهند. كودكان داراى تجربه مرك والدين ممكن است هميشه نسبت به از دست دادن والد از دست رفته احساس يريشانى روانشناختى داشته باشند كه همين احساس مى تواند به ابراز هيجانى پايين و آكاهى ضعيف هيجانى آنها منجر شود زيرا فقدان والد از دست رفته موجب كاهش تشويقها و حمايتهاى وى از نحوه ابراز هيجانى
داشت كه كودكانى كه از يك رابطه نزديك با والد خود محروم هستند احساس امنيت كمترى مى كنند و براى ابتلاء به اختلالات سلوك در معرض خطر بيشترى هستند. همرحنين در راستاى مطالعه حاضر مىتوان به نتايج مطالعه Rosenhan و Seligman اشاره كرد كه بروز علائم احساس حقارت، كنارهيرى اجتماعى، كمرويى، ترس، غم و اندوه مزمن را در كودكان طلاق و جدا مانده از والدين نشان دادند. جنين استنباط مىشود كه اين كودكان ممكن است نسبت به برداشتهاى ديكران از طلاق و مركى والدين ارزيابىهاى منفى داشته باشند كه باعث كنارهيرى آنان از ديكران و كاهش مشاركت اجتماعىشان شود، لذا ممكن است كه احساس كنند ديكران آنها را از نظر اجتماعى نمى يذيرند. اين باور نيز در يك خرخه معيوب منجر به كنارهيرى بيشتر از اجتماع و در نهايت كاهش مقبوليت اجتماعى آنان

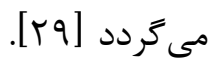
نتايج نشان داد كه ميانكين مشكل در دشوارى در تنظيم هيجان در كروه كودكان طلاق و كروه كودكان داراى تجربه مرك والدين بيشتر از گروه كودكان عادى بود. در مورد مقايسه ابراز هيجان در كودكان طلاق و كودكان داراى تجربه مركى والدين با كودكان عادى تا 
• II مقايسه مقبوليت اجتماعى، اختلالات سلو و و دشوارى در تنظيم هيجان در كود كان طلاق ...

مهارتهاى ارتباطى براى كاهش مشكلات روانى در كودكان طلاق و داراى تجربه مرگ والدين توصيه

مىشود.

\section{نتيجه گَيرى}

يافتههاى اين مطالعه نشان داد ميزان اختلالات سلوى

و دشوارى در تنظيم هيجان در كودكان طلاق بيشتر از كودكان داراى تجربه مرگ والدين و كودكان عادى است و مقبوليت اجتماعى كود كان طلاق از دو گروه ديكر كمتر است. با توجه به اينكه طلاق و مرك والدين منجر به عدم ارضاء نيازهاى عاطفى كودى، تجربه بيش از حد فشارهاى روحى و هيجانهاى منفى ناشى از فقدان والد و اختلال در روابط اجتماعى و روابط بين فردى شده، توصيه مىشود با شناسايى كودكان طلاق و كودكان داراى تجربه مرگ والدين در مدارس خدمات مشاوره و روانشناختى بيشترى براى اين كودكان در نظر گرفته شود. يافتههاى اين يزوهش قابل كاربست توسط دستاندركاران آموزش و يرورش به ويزه روانشناسان و

$$
\text { تشاوران مدارس مىباشد. }
$$

اين مقاله حاصل پايانامه كارشناسى ارشد روانشناسى دانشگاه آزاد اسلامى واحد قم است. محققان بر خود لازم مىدانند از كليه معلمان و دانشآموزان عزيز كه در اجرا و
كودى مىشود. علاوه بر اين، طلاق و مرگ والدين يريشانىهاى روانشناختى زيادى را در كودكان ايجاد مى كند كه از جمله آنها مى توان به افسردگى اشاره كرد كه بر اين اساس مىتوان گفت افسردگى اين كودكان مى تواند در مشكل در ابراز هيجان آنها نقش داشته باشد زيرا در يزوهشهاى كذشته نشان داده شده كه ابراز هيجانى پايين و دو گانكى در ابراز هيجانى با افسردگى در ارتباط است [ـ[ـ]. همرجنين همسو با نتايج اين مطالعه، نتايج مطالعه Qamari و Fakoor نشان داد كه كودكان طلاق از بهداشت روان يايينترى برخوردار هستند و از شيوه مقابله هيجانى و اجتنابى بيشترى استفاده

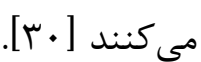
مهممترين محدوديت اين يزوهش خودَزارشدهى افراد گروه نمونه با استفاده از يرسشنامه بود كه ممكن است سوكيرى در ياسخ دادن به سؤالات را به همراه داشته باشد. لذا يِشنههاد مىشود كه در تحقيقات آتى از مصاحبه براى رسيدن به نتايج دقيقتر استفاده شود. همجنين ييشنهاد مىشود در يزوهشهاى بعدى مقايسهاى بين كودكان با از دست دادن يدر و مادر و كودكانى كه تحت تنش والدين هستند يا تحت سريرستى نامناسب قرار دارند، صورت گيرد. با توجه به نتايج حاصل از اين يزوهش انجام آموزشهاى روانشناختى لازم مانند آموزش 
هماهنگَى هاى لازم و حمايت خود انجام اين تحقيق را ميسر

تكميل يرسشنامها ما را يارى كردند تشكر نمايند. همرجنين،

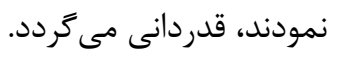

از مسئولين و مديران محترم آموزش و يرورش قم كه با

\section{References}

[1] Edalati A, Redzuan MR. Perception of women towards family values and their marital satisfaction. J Am Sci 2015; 6(4): 132-7.

[2] Amato PR, Marriott BH. A Comparison of high-and low Distress Marriages that end in Divorce. J Marriage Fam 2016; 69(2): 62138.

[3] Johnson VI. Adult children of divorce and relationship education: Implications for counselors and counselor educators. The Family J 2010; 19(1): 22-9.

[4] Martinez-Pampliega A, Aguado V, Corral S, Cormenzana S, Merino L, Iriarte L.
Protecting Children After a Divorce: Efficacy of Egokitzen-An Intervention Program for Parents on Children's Adjustment. J Child Fam Stud 2015; 24(12): 3782-92.

[5] Haji-Hosseini M, Raissi A. Identification of Factors Affecting Parental Divorce Damage in Boys Under the custody of the mother. Policewomen Studies J 2017; 1396(26): 5-28. [Farsi]

[6] Rosenbaum-Feldbrugge M. The Impact of Parental Death in Childhood on Sons' and Daughters' Status Attainment in Young 
Adulthood in the Netherlands. Demogr $J$ 2019; 56: 1827-54.

[7] Ellis J, Dowrick C, Lloyd - Williams M. The Long-Term Impact of Early Parental Death: Lessons from a Narrative Study. J R Soc Med 2013; 106(2): 57-67.

[8] Tebeka S, Hoertel N, Dubertret C, Le Strat Y. Parental Divorce or Death during Childhood and Adolescence and Its Association with Mental Health. J Nerv Ment Dis 2016; 204(9): 678-85.

[9] Amato PR, Anthony CJ. Estimating the Effects of Parental Divorce and Death with Fixed Effects Models. J Marriage Fam 2014; 76: $370-86$.

[10] Bronfen Brenner U. Toward an experimental ecology of human development. American Psychologist 1977; 32: 513-31.
[11] Antonopoulou K, Chaidemenou A, Kouvava S. Peer Acceptance and Friendships among Primary School Pupils: Associations with Loneliness, Self -Esteem and School Engagement. Edu Psychology in Practice 2019; 35: 339-51.

[12] Bayrami M, Movahedi Y, Karazi Notash H, Albort S. Comparison of Social Acceptance and Public Health Students with and without Internet Addiction. Community Health $J$ 2017; 9(2): 20-8. [Farsi]

[13] Beak LE. Development through the lifespan. Translators: Seyed Mohammadi Y. 4th ed, Tehran: Arasbaran; 2007: 669-721. [Farsi]

[14] Ghezelseflo M, Hematipouya S. Effectiveness of emotional regulation training on affective, social and educational adjustment in 10 to 14 years' boys suffering from conduct disorder. J Appl Psychol 2018; 12(2): 183-202. [Farsi] 
[15] Chang CN, Wang W. Conduct disorder in girls: Neighborhoods, family characteristics and parenting behaviors. J Child Adolesc Psychiatr Ment Health 2016; 2, Article ID 28.

[16] Bouragui KE, Wauthia E, Simon A, Rossignol M. Processing of Emotional Facial Expressions (EFE) in Paediatric Anxiety: Are Child Faces More Noteworthy than Adult Faces? Acta Psychopathologica 2017; 3(4): $1-7$.

[17] Ariapooran S, Abbasi M. The Symptoms of Anxiety Disorders, Emotional Expression and Social Acceptance in Students with Parental Divorce and Death Experience and Normal Student. Journal of Family Research 2020; 16(2): 259-83. [Farsi]

[18] Yap K, Mogan C, Moriarty A, Dowling N, Blair-West S, Gelgec C, et al. Emotion regulation difficulties in obsessive- compulsive disorder. J Clin Psychol 2018; 74(4): 695-709.

[19] Heerdink W, Van K, Homan CH. Emotional expressions as social signals of rejection and acceptance: Evidence from the Affect Misattribution Paradigm. J Exp Soc Psychol 2015; 56: 60-8.

[20] Scharfstein L, Beidel DC. Behavioral and Cognitive-Behavioral Treatments for Youth with Social Phobia. J Exp Psychopathol 2011; 2(4): 615-28.

[21] Delavar A. Theoretical and practical foundations of research in humanities and social sciences. 9th ed, Tehran: Roshd; 2011: 133. [Farsi]

[22] Ford LH, Rubin BM. A social desirability questionnaire for young children. $J$ Consult Clin Psychol 1970; 35(2): 195-204. 
| I | I مقايسه مقبوليت اجتماعى، اختلالات سلو و وشوارى در تنظيم هيجان در كود كان طلاق ...

[23] Samouee R, Bagherzadeh H, Sabzevari M. Assessing the reliability of the social acceptability questionnaire of primary school students in Isfahan. Behavioral Science Research 2005; 2(1-2): 6-12. [Farsi]

[24] Spirafkin F, Gado B. Parenting style and mental health in Iranian adolescents. $J$ of Novel Applied Sciences 1984; Available from: www.jnasci.org.

[25] Farzad VA, Emamipour S, Vakil Ghahani F. Evaluation of validity, validity and standardization of pediatric symptoms questionnaire. J of Psychological Researchs 2011; 3(11): 47-57. [Farsi]

[26] Penza-Cliyve S, Zeman J. Initial Validation of Emotion Expression Scale for Children (EESC). J Clin Child Adolesc Psychol 2002; 31(4): 540-7.

[27] Ariapooran S. A Comparative Study of the Symptoms of Anxiety Disorders between
Learning- Disabled and Regular Education Children. Middle Eastern J of Disability Studies 2017; 7:1-6. Available from: URL: http://jdisabilstud.org/article-1-639-fa.html.

[Farsi]

[28] Marchant MR, Solano BR, Fisher AK, Caldarella P, Young KR, Renshaw TL. Modifying socially with drawn behavior: A playground intervention for students with internalizing behaviors. Psychol Sch 2007; 44: 779-94.

[29] Seligman M, Rosenhan D. Abnormal Psychology: Psychopathology Based on DSM-IV (Volume 1). Translator: Seyed Mohammadi Y. 11th ed, Tehran: Savalan; 2011: 405-24. [Farsi]

[30] Qamari M, Fakoor E. Comparison of coping styles with stress and mental health and the relationship between these variables among 
divorced and non-divorced students.

Behavioral Sci 2010; 2(4): 119-32. [Farsi]

[31] Kahani S, Hassanabadi M. Comparison of anxiety and aggression in adolescents 12-19 years of discrete and continuous families.

Scientific J of Birjand Uni of Med Sci 2000;

7(1): 39-42. [Farsi] 
1 11 1 إيسه مقبوليت اجتماعى، اختلالات سلو ك و دشوارى در تنظيم هيجان در كود كان طلاق ...

\title{
Comparison of Social Acceptability, Conduct Disorders, and Difficulty in Emotion Regulation between Children of Divorce, Children with Parental Death, and Normal Children in Qom in 2020: A Descriptive Study
}

\author{
M. Zeraatkar ${ }^{1}$, Sh. Saravani ${ }^{2}$, M. Zeinali Pour ${ }^{3}$, F. Arbabi ${ }^{4}$
}

Received: 03/08/21 Sent for Revision: 07/09/21 Received Revised Manuscript: 06/11/21 Accepted:08/11/21

Background and Objectives: The experience of separation and death of parents can lead to many psychological and behavioral problems. The aim of this study was to determine and compare social acceptability, conduct disorders and difficulty in emotion regulation in children of divorce, children with parental death, and normal children.

Materials and Methods: In this descriptive study, 180 6th-grade and middle school students in Qom in 2020 were selected by purposive and available sampling method, which includes 60 students with parental death, 60 students with divorced parents, and 60 normal students. Ford and Rubin Social Acceptability Questionnaire, Spirafkin and Gado Conduct Disorder Questionnaire, and Penza-Cliyve and Zeman Emotion Regulation Difficulty Questionnaire were used to collect data. Data were analyzed by multivariate analysis of variance (MANOVA).

Results: The findings showed that there is a significant difference among the children with divorced parents, children with parental death experience, and normal children in conduct disorders $(F=50.807, p<0.001)$, difficulty in emotion regulation ( $\mathrm{F}=11.344, \mathrm{p}<0.001)$, and social acceptability $(\mathrm{F}=4.420, \mathrm{p}=0.013)$. Thus, social acceptanbility, conduct disorders and difficulty in emotion regulation were higher in the students with divorced parents than students with parental deaths and normal students.

Conclusion: According to the results of the study, the rate of conduct disorders and difficulty in emotion regulation in the children of divorce is higher than the children with parental deaths and normal children. Therefore, it is recommended to use psychological training and therapies to reduce psychological problems including symptoms of conduct disorders and improve emotion regulation and increase social acceptability in the students experiencing parental divorce and parental death.

Key words: Social acceptability, Conduct disorders, Parental death, Divorce, Children, Qom

Funding: This study did not have any funds.

Conflict of interest: None declared.

Ethical approval: The Ethics Committee of Islamic Azad University of Qom Branch approved the study (IR.IAU.QOM.REC.1400.008).

How to cite this article: Zeraatkar M, Saravani Sh, Zeinali Pour M, Arbabi F. Comparison of Social Acceptability, Conduct Disorders, and Difficulty in Emotion Regulation Between Children of Divorce, Children with Parental Death, and Normal Children in Qom in 2020: A Descriptive Study. J Rafsanjan Univ Med Sci 2022; 20 (10): 1099-116. [Farsi]

1- MA in Family Counseling, Dept. of Family Counseling, Qom Branch, Islamic Azad University, Qom, Iran ORCID: 0000-0003-3712-4085

2- Assistant Prof., Dept. of Psychology, Qom Branch, Islamic Azad University, Qom, Iran, ORCID: 0000-0002-0939-5139

(Corresponding Author) Tel: (025) 32808080, Fax: (025) 32804040, E-mail: shahrzad_saravani@yahoo.com

3- MA in Psychology, Dept. of Psychology, Qom Branch, Islamic Azad University, Qom, Iran, ORCID: 0000-0002-4091-7900

4 MA in Psychology, Dept. of Psychology, Qom Branch, Islamic Azad University, Qom, Iran, ORCID: 0000-0002-2347-4300

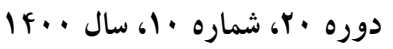

مجله دانشگاه علوم يزشكى رفسنجان 